\title{
AN ANALYSIS: INDONESIA'S NEW NORMAL POLICY IMPLEMENTATION DURING COVID-19 AND ITS IMPACT ON ECONOMIC ASPECT
}

\author{
Helen Dian Fridayani ${ }^{1}$, Muhammad Iqbal ${ }^{2}$ \\ 1,2Graduate Institute of Political Economy, Department of Political Science, \\ Faculty of Social Science, National Cheng Kung University, Taiwan \\ Email: helendianf9@gmail.com
}

\begin{abstract}
This study aims to analyze the new normal policy implementation during Covid-19 to deliverance the economy of Indonesia. New normal is one of the options to become a milestone in Indonesia's economic revival. The government has decided to run a new normal policy to encourage economic recovery. Although, the Covid-19 pandemic has not shown any signs of ending. Previously the handling of Covid-19 in Indonesia by seeking social distancing to large-scale social restrictions. However, this policy seems to make the economy in Indonesia stuck, so the government's step is to implement new normal. The method used in this study is qualitativedescriptive, with secondary data obtained from various sources such as government websites, journals, books, and online media. As a result, this new normal policy is aimed at all business sectors. To support this policy, the government has made working guidelines in new normal situations. If economic activity returns, the most noticeable impact will be reduced unemployment and the availability of various jobs. Therefore, people's purchasing power is expected to recover as before the Covid-19 pandemic emerged. New normal activity amid the Covid-19 pandemic is like two sides of a coin. On the one hand, there is the potential to boost the economy; however, there is a risk of increasing the coronavirus's positive cases. This study found that health protocols can be easily formulated, but implementation may not be comfortable in the field. For this reason, various multidisciplinary studies need to be considered by the government in implementing the new normal policy.
\end{abstract}

Keywords: Covid-19 management, New Normal Policy, Economic Aspect.

\begin{abstract}
Abstrak
Kajian ini bertujuan untuk menganalisis implementasi kebijakan normal baru selama Covid-19 terutama terkait dengan perekonomian Indonesia. Normal baru merupakan salah satu opsi untuk menjadi tonggak kebangkitan ekonomi Indonesia. Pemerintah telah memutuskan untuk mengimplementasikan kebijakan normal baru untuk mendorong pemulihan ekonomi. Meski begitu, pandemi Covid-19 belum menunjukkan tanda-tanda akan berakhir. Sebelumnya penanganan Covid-19 di Indonesia adalah dengan mengupayakan pembatasan sosial hingga skala besar. Namun, kebijakan tersebut tampaknya membuat perekonomian di Indonesia mandek, sehingga langkah pemerintah adalah menerapkan new normal. Metode yang digunakan dalam penelitian ini adalah deskriptif kualitatif, dengan data sekunder diperoleh dari berbagai sumber seperti website pemerintah, jurnal, buku, dan media online. Hasilnya, kebijakan normal baru ini ditujukan pada semua sektor usaha. Untuk mendukung kebijakan tersebut, pemerintah telah membuat pedoman kerja dalam situasi normal baru. Jika kegiatan ekonomi kembali, dampak yang
\end{abstract}


paling terlihat adalah berkurangnya pengangguran dan ketersediaan berbagai lapangan kerja. Dengan demikian, daya beli masyarakat diperkirakan akan pulih seperti sebelum pandemi Covid-19 muncul. Aktivitas normal baru di tengah pandemi Covid-19 seperti dua sisi mata uang. Di satu sisi, ada potensi untuk mendongkrak perekonomian. Namun, ada risiko meningkatnya kasus positif virus Covid-19. Studi ini menemukan bahwa protokol kesehatan dapat dengan mudah dirumuskan, tetapi penerapannya mungkin tidak mudah di lapangan. Untuk itu, berbagai kajian multidisiplin perlu menjadi pertimbangan pemerintah dalam menerapkan kebijakan normal baru.

Kata Kunci: Pengelolaan Covid-19, Kebijakan Normal Baru, Aspek Ekonomi.

\section{INTRODUCTION}

In 2020 was a challenging year for the world when suddenly the Covid-19 outbreak appeared, which initially emerged locally in Wuhan China, then spread and destroyed the joints of the world economy (Jennifer, 2020). As of August 2020, Indonesia has reported 125,396 positive cases, the second-most in Southeast Asia after the Philippines (BNPB, 2020). In terms of mortality, Indonesia is ranked fifth in Asia with 5,723 deaths. However, the mortality rate is estimated to be much higher than the data reported because there are no cases of death with acute COVID-19 symptoms that have not been confirmed or tested (BBC, 2020). Meanwhile, it was announced that 80,952 people had recovered, leaving 38,721 cases currently being treated.

The development of the health crisis that impacts the world economy has practically forced all countries in the world to retreat with predetermined strategic plans, which are then replaced by emergency response policies by mobilizing all resources to overcome the Covid-19 outbreak. Think tanks and strategic thinkers have corrected their projections, especially in 2020, which is likely to see an economic slowdown, recession, and even depression. Development in every country is sure to be disrupted. Each country revises its state budget and provides a large allocation of funds to deal with this corona outbreak. Given the disease comes through the coronavirus is quite deadly (on average, around $3-5 \%$ of deaths from victims who have been exposed to the virus), then patent drugs have not been found. Only preventive solutions are the best way to pursue so that each country can protect every life of its citizens (Wang \& Tang, 2020).

Various countries have implemented lockdown policies to limit the total spread of this virus. However, changing people's social behavior is not an easy job. Various countries, with all their limitations, face challenges that are not simple. Even developed countries in Europe and the United States are very overwhelmed. The general policy that requires people to carry out social and physical distancing (maintaining a safe distance between individuals and avoiding crowds) is not easy for human beings on earth accustomed to their social behavior (Fang, Nie, \& Penny, 2020). The lockdown policy was then modified in such a way by various countries. Some apply in full, partially, or locally and to a minimum. Then, in early June, the Indonesian government began implementing the new normal 
policy. The definition of new normal is a scenario to accelerate the handling of COVID-19 in health and socio-economic aspects (Isyunanda, 2020). The Indonesian government has announced plans to implement the new normal scenario taking into account epidemiological studies and regional preparedness (Charles, 2020). Local governments are allowed to prepare a new normal if their area is at a moderate level. Several sectors are preparing the standard operating procedure for the new normal scenario.

Several studies have explained that a habit that is continuously carried out will become a new habit. On this point, almost all social researchers are in the same opinion. The difference lies in how long it takes to form a new habit. Some experts determine how long it takes for a new habit to be created, among others, 21 days to form a new habit (Maxwell, 2020). However, Lally, et al. (2010) from University College London said her study set an average of 66 days for turning habits into habits (Lally, Jaarsveld, Cornelia H, M, Potts, \& Wardle, 2010). The principle of the new normal is to be able to adapt to life patterns. This transformation is to organize new lives and behaviors during a pandemic, which will then be carried forward until a vaccine is found for Covid-19 (Sitorus, 2020). To familiarize the people, the Task Force Team was formulate a movement entitled four healthy five perfect (Zahrotunnimah, 2020). This movement is not the same as pre-existing food consumption patterns. This is more aimed at preventing the transmission of the corona virus.

Some countries implemented a new normal policy, including Indonesia. New normal is intended to continue to carry out its functions according to the constitution. The government can carry out its function of taking care of the people if there is an income of state treasury from taxes and other state revenues. If economic activities stop, then the state will have no income, affecting the people. Apart from that, New Normal has enforced the full awareness that the plague is still around us.

For this reason, all public activities are permitted on the condition that they use established health protocols. New normal is done because not everyone can survive by living at home without any financial income to make ends meet. Everyone needs to eat and provide for their families. Therefore, the new normal is a solution that needs to be done in the face of a pandemic that does not know when it will end. The new normal policy is still integrated with the community protection and safety net program for citizens who need it without reducing the focus on providing health services for handling Covid-19 victims. Therefore, this paper will attempt to analyze how the new normal implementation in Indonesia has a particular impact on the Indonesian economy.

\section{RESEARCH METHOD}

The method used in this research is a qualitative approach with content analysis. The purpose of this qualitative content analysis research is actually systematic and analytical, but not rigid like quantitative content analysis (Nazir, 2013). In other words, quantitative content analysis can only identify or identify the manifest messages (messages that appear) from the content of the media under study. Meanwhile, qualitative content 
analysis can identify manifest messages and latent messages from a document under study. Therefore, it is better able to see the tendency of media content based on context (social situation around the document or text understudy), process (how a media production process/message content is actually created and organized together), and emergence (gradual formation of meaning a message through understanding and interpretation) of the documents studied (Bungin, 2004). In this case, to explain the implementation of the new normal policy that is carried out in Indonesia, it mainly analyzes the social media, protocols and regulations or documents used to carry out the policy.

\section{FINDINGS AND DISCUSSION}

After nearly 6 months we are facing the Covid-19 Virus pandemic, the impact is felt by the community in terms of health, social, economic, educational, political and development. The community has a huge impact when they have to limit themselves to not traveling/doing activities outside the house, not gathering, not going to school and not being able to work for a living as usual (Abdini, 2020). Many community activities outside the home or in crowds regulate large-scale policies including economic activities that are at risk of transmitting the corona virus. There have been many things that we have gone through during the period of fighting this pandemic, and have had a very significant impact on meeting the needs of society (Setiaji, 2020). Following are the impacts that occurred during the pandemic and the implementation of large-scale social distancing policies:

a) The community could not make a living as usual, so their income decreased and they were even fired from their jobs. The people who are directly affected are those who work who rely on daily income such as motorcycle taxi drivers, public transport drivers, shops, street vendors. The impact of not being able to earn a living is very influential for families to make ends meet. Economic difficulties have made some families unable to meet their needs for food, pay for rent/boarding house, pay installments for houses / vehicles and so on.

b) Many business fields have closed, such as offices, malls, shops, cinemas, recreation/ tourist areas, hotels, public transportation services, and others. This has an impact on reduced income even to the point of bankruptcy (bankruptcy) and a reduction in the number of employees' salaries to the point of massive layoffs. So many employees have lost their jobs during the corona virus pandemic.

c) The field of education, especially schools and universities/colleges, must close students to carry out online teaching and learning activities at home. The demands of studying at home online make parents have to prepare a fee to buy an internet package, while not all parents have sufficient economic capacity during the pandemic.

Two months after the implementation of Large-Scale Social Restrictions, the Government of Indonesia is now implementing it to roll back the economy that was sluggish as a result of the implementation of the large scale social restrictions (Lidwina, 2020). The Indonesian Government's 
intention to return to turning the wheels of the economy was first seen when President Joko Widodo revealed that the Indonesian people must live in peace with Covid-19 until an effective vaccine is found. The statement is then further translated into a term that has become the talk of many people lately, namely "New Normal" (Setiaji, 2020).

A new normal scenario has been prepared by the Coordinating Ministry for Economic Affairs and comes into effect since June 1, 2020, where industries and services can operate according to health protocols (Jayani, 2020). In the initial plan, there are five new normal phases, namely 1 June, 8 June, 15 June, 6 July and 20 July (Syahni, Della \& Karokaro, 2020). Massive preparations for a new era of normality were marked by President Joko Widodo's visit to various strategic points to monitor preparations for the new normality, one day after the Eid holiday. On other side, the public will be vulnerable to contracting the virus if the precautionary protocol is relaxed (Pranita, 2020). On the other hand, forcing people to stay at home will also have a severe impact on the economy, as the data presented above shows.

In the new normal, there is a change in norms, values, and people's behavior in interacting both with others and with their environment. Even though they return to their daily activities, there is something new that must be done by each individual, namely changing their behavior and habits so far. For example, if you usually go out without a mask, you must now wear a mask. Even have to limit physical distance with others so that the Covid-19 outbreak does not infect them. The habit of washing hands frequently is also something that must be done so that they can prevent the transmission of Covid-19. Likewise, the habit of gathering with colleagues for one thing has also begun to be limited in the work environment, school, club, sports venue, tourism, places of worship, and so on. The scenario for implementing the new normal in Indonesia is as follows:

\section{a) Phase I: June 1, 2020}

1. Industry and Business to Business services operate with social distancing and health requirements

2. Figures, markets and malls cannot yet operate, except for masks selling shops and health facilities

3. The health sector operates fully with due regard to the capacity of the health system

4. Gather a maximum of two people in a room, yet outdoor sports allowed

b) Phase II: 8 June 2020

1. Public figures, markets and malls are allowed to open shops without sector discrimination by applying strict protocols

2. Businesses with physical contact cannot operate

3. Gathering and outdoor sports are not allowed

c) Phase III: 15 June 2020

1. Stores, markets and malls remain in phase II, evaluating the opening of salons, spas and others with health protocols

2. Cultural activities are allowed while maintaining a distance 
3. Educational activities in schools are carried out using a shift system according to the number of classes

4. Outdoor sports are allowed by protocol

5. Evaluation of opening of wedding venues, birthdays, social activities for up to 10 people

\section{d) Phase IV: July 6, 2020}

1. Opening of economic activities as in phase III with additional evaluation

2. Gradual opening of restaurants, cafes, bars, gyms and others with protocol cleanliness is strict

3. Outdoor activities of more than 10 people

4. Travel out of town with restrictions on the number of flights

5. Worship activities are carried out in a limited number

6 . Limiting activities on the scale of more than specified

\section{e) Phase V: 20 and 27 July 2020}

1. Evaluation for phase IV and opening of other economic places or activities on a large scale

2. End of July or early August all economic activities have been opened. Stick to strict hygiene and health protocols and standards

3. Periodic evaluation until a vaccine can be found and disseminated

However, some experts say that the current implementation of the new normal is not appropriate, because there are no signs of a decline in the number of positive cases in Indonesia. In fact, the new normal policy should be implemented on the condition that there is a significant decrease in the number of positive cases. In Indonesia alone, positive cases of Covid-19 still show a fluctuating nature, where there are still ups and downs in the number of cases in the range of 500-900 cases per day (Isyunanda, 2020).

In contrast to countries that have implemented the new normal, such as South Korea and Australia. The implementation of the new normal in that country was carried out after a significant decrease in positive cases (Sugihamretha, 2020). Indeed, the application of the new normal should be carried out in accordance with the applicable provisions. The implementation of the new normal in Indonesia is being discussed in early June. This is said to seem very early and in a hurry (Buana, 2020). Several experts in Indonesia then gave their opinion. One of them is the Epidemiology Expert from the University of Indonesia said whether or not the new normal will be enforced depends on the results of the evaluation (Ketchell, 2020). It is necessary to consider the results of the epidemiological evaluation first and then to be applied gradually, and these preparations cannot be applied at the same level for all regions of Indonesia (Heriani, 2020).

This new normal policy is indeed carried out in order to restructure human life and activities with new things (Habibi, 2020). This new normal policy was also carried out in order to restore the national economy. As we know, several sectors died as a result of this pandemic. The incentives that have been given by the government for various sectors are also considered unable to save their economy (Syahni, Della \& Karokaro, 2020). Bank Indonesia also projects Indonesia's economic growth to be below 5 percent 
or only around 2.5 percent, even though Indonesia's economic growth has grown at around 5.02 percent (Nurjanah, 2020). Not only that, the spread of Covid-19 throughout Indonesia led to massive layoffs by several companies in Indonesia.

As long as the new normal Indonesian economy starts to run as usual, it has not shown significant significance because the biggest supports of state income are from SMEs and tourism. Life goes on normally with the protocol set by the government. However, the number of positive patients with Covid-19, with the implementation of the new normal, has even increased to 200 thousand people, and 100 doctors have died. Of course, this should be a concern for the government to review this new normal policy in Indonesia.

\section{CONCLUSION AND RECOMMENDATION}

Covid-19 as a global pandemic has significance for various aspects of the life of society, nation and state. Of the various aspects affected are economic aspects. At an economic level, the Covid-19 pandemic has had a major impact on the national microeconomics and macroeconomics. In the microeconomic context, for example, industry players or providers of goods and services, like it or not, have to suffer significant losses due to a decrease in demand (demand) as a consequence of the government's social restriction policies. At a further level, large-scale industry players must reduce or even stop their operations due to the decrease in demand. This factor has in turn sparked a massive wave of layoffs (PHK) and in the end it has the potential to become a time bomb because sooner or later if the government is unable to solve it, it will cause new social problems. So many sectors affected by Covid-19 have paralyzed the wheels of the economy of the community, both from the upper, middle to lower classes, all of which are affected. When referring to contemporary political thought, it is clear that the State, in this case the Government, is responsible for fulfilling the economic and social rights of its people. As also issued by WHO, the government (especially the Central Government), has full obligations. Not only to provide health services to residents affected by corona, but also to support all the factors that determine the spread of the virus can be stopped, both guarantees of food availability, access to accurate information, and so on.

In entering into this new normal, one must find the midpoint of importance between health and the economy. In the face of the Covid-19 pandemic, both the central and regional governments should cooperate with each other in a compact manner and forget about their respective sectoral egos because this concerns the lives of many people, so that the people are no longer overshadowed by worries and the people believe that the government is capable of handling the Covid-19 pandemic. this as well as possible, in order to protect and save the people from the threat of Covid-19. The government should prioritize the safety of the people rather than economic issues, especially the celebration of post-conflict local elections which should not be a priority in the midst of this kind of pandemic, considering that in the highest constitution a country is to guarantee the safety of its people. The government (especially the central government), is 
fully responsible not only for providing health services to residents affected by corona, but also supporting all the factors that determine that the virus can be stopped from spreading, including guarantees of food availability, access to accurate information, and so on.

\section{REFERENCES}

Abdini, C. (2020, March 25). BAGAIMANA PEMERINTAH HARUS BERTINDAK DALAM SKENARIO TERBURUK WABAH COVID-19. Akademi Ilmuan Muda Indonesia. Retrieved from https: / /almi.or.id/2020/03/25/bagaimana-pemerintah-harusbertindak-dalam-skenario-terburuk-wabah-covid-19/

BBC. (2020, April 1). Virus corona: "Status Kedaruratan Kesehatan Masyarakat" dan Pembatasan Sosial Berskala Besar, yang boleh dan tidak boleh. $B B C$ Indonesia. Retrieved from https: / / www.bbc.com/indonesia/indonesia-52109439

BNPB. (2020, April 9). Empat Strategi Pemerintah Atasi COVID-19. BNPB. Retrieved from https://bnpb.go.id/berita/empat-strategi-pemerintahatasi-covid 19

Buana, D. R. (2020). Analisis Perilaku Masyarakat Indonesia dalam Menghadapi Pandemi Virus Corona ( Covid-19) dan Kiat Menjaga Kesejahteraan Jiwa Analisis Perilaku Masyarakat Indonesia dalam Menghadapi Pandemi Virus Kata Kunci: Sosial \& Budaya Syar-I, (March). https://doi.org/10.15408/sjsbs.v7i3.15082

Bungin, B. (2004). Metode Penelitian Kualitatif (1st ed.). Jakarta: Penerbit:PT Rajagrafindo Persada.

Charles, P. (2020). Going beyond the ' new normal' in Indonesia 'New Normal ' in Indonesia Going Beyond the. 6-10.

Fang, Y., Nie, Y., \& Penny, M. (2020). Transmission dynamics of the COVID 19 outbreak and effectiveness of government interventions: A data driven analysis. Medical Virology, (March). https://doi.org/10.1002/jmv.25750

Habibi, A. (2020). Normal Baru Pasca Covid-19. Journal.Uinjkt.Ac.Id, 4(1), 197-202. https://doi.org/10.15408/adalah.v4i1.15809

Heriani, F. N. (2020, March). Kebijakan dan Kesigapan Pemerintah Kunci Tangani Dampak Covid-19. Hukumonline.Com. Retrieved from https://www.hukumonline.com/berita/baca/1t5e82bdc2d2dd6/kebijak an-dan-kesigapan-pemerintah-kunci-tangani-dampak-covid-19

Isyunanda, K. P. (2020, June 15). Covidnomics: New normal? The Jakarta Post. Retrieved from https: / /www.thejakartapost.com/academia/2020/06/15/covidnomicsnew-normal.html

Jayani, D. H. (2020, April 22). Posisi Kesiapan Indonesia di Dunia Hadapi Ledakan Covid-19. Katadata.Com. Retrieved from https: / /katadata.co.id/analisisdata/2020/04/22/posisi-kesiapanindonesia-di-dunia-hadapi-ledakan-covid-19

Jennifer, M. (2020). Characteristics of and Important Lessons From the Coronavirus Disease 2019 ( COVID-19) Outbreak in China Summary of a Report of 72314 Cases From the Chinese Center for Disease Control and 
Prevention. 323(13).

Ketchell, M. (2020, March 27). Analisis: Pemerintah masih bisa perbaiki komunikasi krisis pandemi yang sejauh ini gagal. The Conversation. Retrieved from https://theconversation.com/analisis-pemerintahmasih-bisa-perbaiki-komunikasi-krisis-pandemi-yang-sejauh-ini-gagal134542

Lally, P., Jaarsveld, Cornelia H, M, V., Potts, H. W. W., \& Wardle, J. (2010). How are habits formed: Modelling habit formation in the real world. European Journal of Social Psychology Eur., 4O(June 2009), 625-634. https: / / doi.org/10.1002/ejsp

Lidwina, A. (2020, May 8). Simalakama Mitigasi Covid-19, Kesehatan atau Ekonomi? Katadata.Com. Retrieved from https: / /katadata.co.id/analisisdata/2020/05/08/simalakama-mitigasicovid-19-kesehatan-atau-ekonomi

Maxwell, M. (2020, November). Psycho-Cybernetics: Updated and Expanded. TarcherPerigee. Retrieved from https://www.amazon.com/PsychoCybernetics-Updated- Expanded-Maxwell-Maltz/dp/0399176136

Nazir, M. (2013). Metode Penelitian. Bogor: Ghalia Indonesia.

Nurjanah. (2020). Semangat Bela Negara Untuk Menghadapi COVID-19 Di Indonesia.

Pranita, E. (2020, April 2). Berbagai Respons Rakyat untuk Pemerintah Terkait Penanganan Covid-19. Kompas. Retrieved from https: / /www.kompas.com/sains/read/2020/04/02/100200323/berba gai-respons-rakyat-untuk-pemerintah-terkait-penanganan-covid-19

Setiaji, H. (2020, June 3). Kenapa New Normal Begitu Penting? CNBC Indonesia.

Sitorus, R. (2020, April 12). Jabar Terapkan PSBB, Anggaran Penanganan COVID-19 Diperkirakan Rp7,59 Triliun. Kabar24.Com. Retrieved from https://kabar24.bisnis.com/read/20200412/15/1225688/jabarterapkan-psbb-anggaran-penanganan-covid-19-diperkirakan-rp759triliun

Sugihamretha, I. D. G. (2020). Respon Kebijakan: Mitigasi Dampak Wabah Covid-19 Pada Sektor Pariwisata. Jurnal Perencanaan Pembangunan: The Indonesian Journal of Development Planning, 4(2), 191-206. https://doi.org/10.36574/jpp.v4i2.113

Syahni, Della \& Karokaro, A. S. (2020, April 6). Cara Mereka Antisipasi Virus Corona agar Wilayah Tak Tertular. Mongobay.Co.Id. Retrieved from https://www.mongabay.co.id/2020/04/06/cara-merekaantisipasi-virus-corona-agar-wilayah-tak-tertular/

Wang, Z., \& Tang, K. (2020). Combating COVID-19: health equity matters. Nature Medicine, 26(April), 2020. https://doi.org/10.1038/s41591-0200823-6

Zahrotunnimah. (2020). Langkah Taktis Pemerintah Daerah Dalam Pencegahan Penyebaran Virus Corona Covid-19 di Indonesia. Sosial \& Budaya Syar-I, 7(3), 247-260. https://doi.org/10.15408/sjsbs.v7i3.15103 